\title{
Isolation of anti-mycobacterial compounds from Curtisia dentata (Burm.f.) C.A.Sm (Curtisiaceae)
}

\author{
Victor O. Fadipe ${ }^{1}$, Nkoana I. Mongalo ${ }^{2 *}$, Andy R. Opoku ${ }^{3}$, Preachers M. Dikhoba ${ }^{4}$ and Tshepiso J. Makhafola ${ }^{4}$
}

\begin{abstract}
Background: Tuberculosis is counted amongst the most infectious and lethal illnesses worldwide and remains one of the major threats to human health. The aim of the current study was to isolate and characterize antimycobacterial compounds present in Curtisia dentata (Burm.f.) C.A.Sm, a medicinal plant reportedly used in the treatment of tuberculosis, stomach ailments and sexually transmitted infections.

Methods: The bioassay guided principle was followed to isolate the anti-mycobacterial compounds. The crude ethanol extracts of the leaves was partitioned with various solvents four compounds such as $\beta$-sitosterol, betulinic acid, ursolic acid and lupeol were successfully isolated. The compounds and their derivatives were evaluated for anti-mycobacterial activity using Microplate Alamar Blue Assay (MABA) against Mycobacterium tuberculosis H37RV (ATCC 27294). Furthermore, the derivatives were investigated for their toxicity against HepG2 and HEK293 using the MTT assay.

Results: The methanol fraction had the lowest minimum inhibitory concentration (MIC) of $22.2 \mu \mathrm{g} / \mathrm{ml}$ against the selected Mycobacterium strain when compared to other fractions. Ursolic acid acetate (UAA) was the most active compound with MIC value of $3.4 \mathrm{\mu g} / \mathrm{ml}$. The derivatives had varying degrees of toxicity, but were generally nontoxic to the selected cell lines. Derivatives also exhibited highest selectivity index and offers a higher safety margin.

Conclusions: The derivatives had better antimicrobial activity and low cytotoxic effects compared to isolated compounds. These increased their selectivity. It appears that acetylation of both betulinic acid and ursolic acid increased their activity against the selected Mycobacterium species. The results obtained in this study gives a clear indication that Curtisia dentata may serve as major source of new alternative medicines that may be used to treat TB. Furthermore, there is a need to explore the activity of these tested plant against other pathogenic Mycobacterium species.
\end{abstract}

Keywords: Curtisia dentata, Anti-mycobacterial activity, Cytotoxicity, $\beta$-sitosterol, Ursolic acid

\section{Background}

Approximately three million people die due to tuberculosis (TB) each year. This renders the disease a major public health problem [1]. Several drugs such as rifampicin, isoniazid, ethambutol and pyrazinamide have been used in the treatment of TB over a period of six months [2]. However, there are still other emerging forms of TB such as multi-drug resistant (MDR) and extensively drug

\footnotetext{
* Correspondence: Mongani@unisa.ac.za

${ }^{2}$ College of Agriculture and Environmental Sciences (CAES) Laboratories, Eureka Building-Laboratory 139, University of South Africa, Private Bag X6, Florida, Johannesburg 0710 , South Africa

Full list of author information is available at the end of the article
}

resistant (XDR) [3-5] and the situation is compounded by the close relationship and co-infection of the disease with HIV-AIDS. In most parts of the world, particularly Africa, the use of herbal medicines is preferred over treatments recommended by western medicine [6], sometimes because of tradition, culture and beliefs. Worldwide, medicinal plants used in the treatment and management of tuberculosis and the related infections have been documented [7-12].

Although TB research has gained momentum, the discovery of new anti-mycobacterial drugs is low. Drugs currently used to treat $\mathrm{TB}$ were mostly discovered 
between 1950s and 1970s [13, 14]. There is an increase in the investigations of anti-tubercular activity of plant extracts and isolated compounds from various medicinal plants [15-20]. However, little is known about the mode of action of such extracts and the efficacy of derivatives of such compounds against various tuberculosis agents.

Curtisia dentata (Burm.f.) C.A. Sm is a medium sized to a large tree with brownish stem bark when matured, and simple, opposite, broadly elliptic, serrate and oblong leaves [21]. The plant species has been reported to treat a variety of infections including malaria, diarrhea, stomach ache, tuberculosis and sexually transmitted infections amongst the Sotho tribes of South Africa. The plant species is unsustainably harvested, scarce and heavily traded with a high price tag in South Africa [22]. The current work is aimed at investigating the antimycobacterial activity of fractions, the isolated compounds and the derivatives from the leaves of $C$. dentata leaves. Furthermore, to explore the cytotoxicity of the derivatives against HepG2 and HEK 293 cell lines and determine their selectivity index values.

\section{Methods}

\section{Plant collection}

Fresh leaves of Curtisia dentata $(3 \mathrm{~kg})$ were collected from Buffelskloof Private Nature Reserve in Mpumalanga province (South Africa) in March 2014. The plant was authenticated and identified by Mr. John Burrows, Botanist/ Reserve Manager, Buffelskloof Private Nature Reserve and a voucher (specimen No: B.C.Turpin-2062) was been deposited in the Herbarium of the Buffelskloof Private Nature Reserve, Mpumalanga, South Africa.

\section{Extraction and isolation}

The air-dried leaves of Curtisia dentata (150 g) were extracted repeatedly (3 times) with ethanol at room temperature. The combined ethanolic extracts were freed of the solvent using rotary evaporator to a thick syrup. The crude extracts was suspended in water and partitioned with hexane, methylene chloride and acetone. The resulting fractions were kept in a refrigerator until needed for biological assays.

\section{Isolation of $\beta$-sitosterol from Curtisia dentata leaves}

The dried ethanol extract $(8 \mathrm{~g})$ was subjected to column chromatograph $(40.5 \times 530.5 \mathrm{~mm})$ using silica gel 60 (180 g, 0.04-0.063 mm; 230-400 mesh) supplied by Merck (Darmstadt, Germany). The ethanol extracts were chromatographed using gradient elution of hexane-ethyl acetate in a $10 \%$ increase and collecting $80 \mathrm{~mL}$ fractions. Twenty-five (25) fractions were collected and monitored based on their TLC (F254-Merck, Whitehouse Station, NJ, USA) by visualization was achieved by UV light (254 nm) and spray with $20 \% \mathrm{H}_{2} \mathrm{SO}_{4}$ in $\mathrm{MeOH}$ followed by heating in the oven $\left(105^{\circ} \mathrm{C}\right)$. Compound I (89.34 mg) was obtained from fractions $7-11$ as single spot and then analyzed for purity using IR, HR-MS and NMR spectra.

\section{Spetroscopic analysis}

Infra-red (IR): The infra-Red (IR) spectroscopy determination was carried out using Perkin Elmer Spectrum 100 FTIR spectrometer. Nuclear magnetic resonance (NMR): ${ }^{1} \mathrm{H},{ }^{13} \mathrm{C}$ NMR and all 2D spectra were recorded on a Bruker Avance instrument operating at $400 \mathrm{MHz}$, Chemical shifts are reported as $\delta$ values (ppm) relative to an internal standard of tetramethylsilane (TMS) or to the solvent line of $\mathrm{CDCl} 3(\delta \mathrm{H}=7.26 \mathrm{ppm}$, $\delta \mathrm{C}=77.16 \mathrm{ppm})$. High-resolution-mass spectroscopy (HR-MS): High-resolution mass data were obtained using a Bruker micro TOF-Q II ESI instrument operating at ambient temperature. Melting point (mp): Melting points of the compounds were determined on a Stuart Scientific SMP3 apparatus. The currently isolated compound (1) was isolated and identified as $\beta$-Sitosterol (NMR data not shown), while the other three compounds (2, 3 and 4 ) were identified earlier in our research group [23].

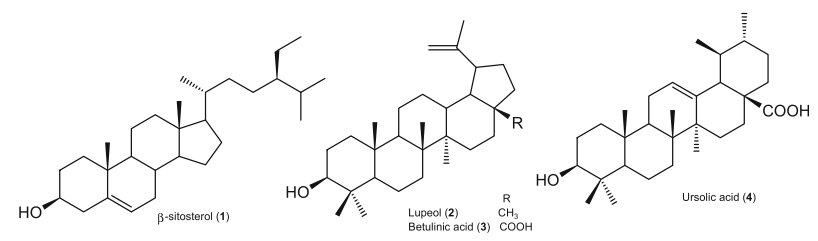

Preparation of 3-O-acetyl-betulinic acid

A mixture of betulinic acid ( $250 \mathrm{mg})$, acetic acid anhydride $(10 \mathrm{ml})$ and pyridine $(3 \mathrm{ml})$ was stirred at $40{ }^{\circ} \mathrm{C}$ for $6 \mathrm{~h}$. The mixture was then transferred into water and stirred for $1 \mathrm{~h}$ at room temperature for hydrolysis. Thereafter, the mixture was filtered and diluted with hydrochloric acid (10\%) to remove any traces of pyridine. The residue was dried and packed into a small column eluted with ethyl acetate: hexane (1:9) ratio to afford a white amorphous powder (138 mg, 55.2\%)

\section{Preparation of 3-O-acetyl-Ursolic acid}

A mixture of ursolic acid $(250 \mathrm{mg})$, acetic acid anhydride $(10 \mathrm{ml})$ and pyridine $(3 \mathrm{ml})$ was stirred at $40^{\circ} \mathrm{C}$ for $6 \mathrm{~h}$. The mixture was transferred into water and stirred for $1 \mathrm{~h}$ at room temperature for hydrolysis. It was then filtered and diluted with hydrochloric acid (10\%) to remove any traces of pyridine. The residue was dried and packed into a small column eluted with ethyl acetate: hexane (1:9) ratio to afford a white amorphous powder (127 mg, 50.8\%). 


\section{Anti-mycobacterial evaluation}

\section{Bacterial strains for anti-TB biological assay}

For the preparation of the inoculum, a virulent strain of M. tuberculosis (H37Rv, ATCC 27294) bacteria was grown in $100 \mathrm{ml}$ of Middlebrook 7H9 Broth (Difco, Detroit, MI), supplemented with $0.2 \%(v / v)$ glycerol (Sigma Chemical Co., St Louis, MO), 10\% (v/v) OADC (oleic acid, albumin, dextrose, catalase; Difco) and 0.05\% $(v / v)$ Tween 80 (Sigma).

\section{Microplate Alamar Blue Assay (MABA)}

Anti-TB susceptibility testing of isolate and synthesized product was determined using the fluorometric Microplate Alamar Blue Assay (MABA) as described previously $[24,25]$. The extracts MICs against MTB H37RV (ATCC 27294) were assessed using rifampin, Streptomycin, TMC207 and isoniazid as positive controls. Sample stocks were prepared in 5\% DMSO and two fold dilutions of compounds were prepared in Middlebrook 7H12 medium (7H9 Broth containing 0.1\% $w / v$ casitone, $5.6 \mu \mathrm{g} / \mathrm{mL}$ palmitic acid, $5 \mathrm{mg} / \mathrm{mL}$ bovine serum albumin, $4 \mathrm{mg} / \mathrm{mL}$ catalase, filter-sterilized) in a volume of $100 \mu \mathrm{L}$ in 96-well Microplates (BD Optilux, 96- well Microplates, black/clear flat bottom). MTB cultures $\left(100 \mu \mathrm{L}\right.$ inoculum of $\left.2 \times 10^{5} \mathrm{cfu} / \mathrm{mL}\right)$ were added, yielding a final testing volume of $200 \mu \mathrm{L}$. The plates were incubated at $37{ }^{\circ} \mathrm{C}$. On the seventh day of incubation $12.5 \mu \mathrm{L}$ of $20 \%$ Tween 80 , and $20 \mu \mathrm{L}$ of Alamar Blue (Invitrogen BioSource ${ }^{\mathrm{Ta}}$ ) were added to the wells. After incubation at $37{ }^{\circ} \mathrm{C}$ for $16-24 \mathrm{~h}$, fluorescence of the wells was measured (ex 530, em $590 \mathrm{~nm}$ ). The MIC was determined as the lowest concentration effecting a reduction in fluorescence of $\geq 90 \%$ relative to the mean of replicate bacteria-only controls. The experiment was repeated three times.

\section{Cytotoxicity studies}

The cytotoxicity studies were carried out using MTT Cell Proliferation Assay [26] and were repeated three times independently. The Human embryonic kidney (HEK293) and Human hepatocellular carcinoma (HepG2) cells were all grown to confluency in MEM supplemented with Glutmax and 10\% Fetal bovine serum in $25 \mathrm{~cm}^{3}$ flasks, trypsinized and plated in 96 well plates at seeding density of $2.3 \times 10^{4}$ cells per well. Cells were incubated overnight at $37{ }^{\circ} \mathrm{C}$ and $5 \% \mathrm{CO}_{2}$. Medium was then removed and fresh medium (MEM + Glutmax + antibiotics) was added. Isolated compounds $(50-500 \mu \mathrm{g} / \mathrm{ml})$ were then added in triplicate and incubated for $48 \mathrm{~h}$. Thereafter medium was removed and replaced by complete medium. After $48 \mathrm{~h}$, the cells were subjected to the MTT assay and the results for different concentrations were read, using Microplate reader (Meter tech. $\Sigma$ 960, U.S.A.) at $570 \mathrm{~nm}$. The wells with cells only were used as control. The percentages of inhibition were then calculated using the formula below.

Percentage cell inhibition $=\mathbf{1 0 0}-$ Abs (Sample)/ Abs (Control) x 100 [27], while the $\mathrm{IC}_{50}$ were obtained from the logarithmic curve of \% inhibition v/s concentrations. The Selectivity index was calculated as follows:

$$
\mathrm{SI}=\mathrm{LD}_{50} \text { in } \mu \mathrm{g} / \mathrm{ml} / \mathrm{MIC} \text { in } \mu \mathrm{g} / \mathrm{ml}[28] \text {. }
$$

\section{Results and discussions}

\section{Anti-mycobacterium activity}

Tuberculosis is ranked second after HIV-AIDS as the leading cause of death worldwide [29]. Although Western methods of healing may be preferred by modernized individuals, the traditional medicines still serve as a primary health care system preferred in developing countries. The results for both the anti-mycobacterial and cytotoxic activity of fractions, isolated compounds and derivatives from Curtisia dentata are shown in Table 1. The methanol fraction was the most active with minimum inhibitory concentration (MIC) of $22.2 \mu \mathrm{g} / \mathrm{ml}$; this is followed by acetone extracts with minimum inhibitory concentration of $44.2 \mu \mathrm{g} / \mathrm{ml}$. The chloroform fraction and ethanol extracts had MIC values of $>50 \mathrm{mg} /$ $\mathrm{ml}$ against the selected Mycobacterium strain. The implication on fractional extracts in the current study is that the compounds responsible for the activity in the plant extracts may have been more soluble, abundantly and highly distributed between the methanol and acetone as moderately polar solvents. The isolated compounds had $\mathrm{MIC}$ values of greater than $50 \mu \mathrm{g} / \mathrm{ml}$. On the contrary, ursolic acid purchased from Sigma Aldrich (Germany) revealed a potent MIC values ranging from 10 to $20 \mu \mathrm{g} /$ $\mathrm{ml}$ against the same Mycobacterium species in the resazurin assay [30]. Besides differences in terms of assays and agar medium used in maintaining the organism, the level of purity of the compound may also play a role in the different results obtained. A mixture of oleanoleic acid and ursolic acid revealed an MIC value of $62.5 \mu \mathrm{g} /$ $\mathrm{ml}$ against $M$. tuberculosis while a mixture of lupeol, $\beta$ amyrin and alpha amyrenone revealed an MIC value of $312.25 \mu \mathrm{g} / \mathrm{ml}$ [31].

In the current study, the fractions revealed better inhibition of $M$. tuberculosis compared to the isolated compounds. Contrarily, [32] reported the isolated compounds to possess more anti-tubercular activity compared to fractions.

In the current study, ursolic acid acetate (UAA) and betulinic acid acetate (BAA) revealed the most potent anti-tubercular activity compared to both the fractions and the isolated compounds, revealing the MIC values of 3.4 and $19.8 \mu \mathrm{g} / \mathrm{ml}$ respectively. These results are in accordance with those of [33], which revealed that the derivatives possess much higher anti-tubercular activity compared to the parental compound isolated from plant 
materials. The anti-tubercular activity observed in the current work is much greater on derivatives followed by fractions and then isolated parent compounds. The outer cell wall of the Mycobacterium is unique because it possess the lipid rich bilayer that consist of mycolic acidhigh molecular weight fatty acids which contains 60 to 90 carbon atoms with a basic $\beta$-hydroxyl- $\alpha$-alkyl branched structure [34]. For that reason, in the quest to find new drugs, the focus should be on the plant materials with potential to inhibit mycolic acid and this may well explain the lengthy treatment given to patients. However, we still need to further assess the antimycobacterial activity of the active plant materials from C. dentata and further study the possible mode of action of such extracts, compounds and derivatives.

Earlier, our research group investigated the antimicrobial potential of leaf extracts from $C$. dentata against organisms that may cause sexually transmitted infections and opportunists isolated from immunocompromised HIV patient [35-37]. The acetone extract had the lowest MIC value of $0.01 \mathrm{mg} / \mathrm{ml}$ against $C$. albicans while ethanol extract had an MIC value of $0.10 \mathrm{mg} / \mathrm{ml}$ against $M$. hominis. Furthermore, the diethyl ether extract had MIC values of $3.13 \mathrm{mg} / \mathrm{ml}$ against Escherichia coli, Proteus mirailis and Moraxella catarrhalis, thereby validating the use of the plant species in the treatment of sexually transmitted and related urinary tract infections. In the antioxidant assay, the acetone extract had up to $52 \%$ inhibition of DPPH at $1 \mathrm{mg} / 100 \mathrm{ml}$.

Assuming the MIC and $\mathrm{IC}_{50}$ to be at 50 and $300 \mu \mathrm{g} / \mathrm{ml}$ respectively, the selectivity index (SI) of the isolated compounds and derivatives was calculated. Betulinic acid and $\beta$-sitosterol have a potent SI value of 6 in both cell lines. The safety margin of the two compounds is better guaranteed compared to that of lupeol and ursolic acid.

In the cytotoxicity studies, the selected derivatives and isolated compounds exhibited some varying degrees of toxicity (Table 1). Generally, the isolated compounds were not toxic to cell lines used in the current study. Lupeol had an $\mathrm{IC}_{50}$ of 278.8 and $289.4 \mu \mathrm{g} / \mathrm{ml}$ against HEK 293 and HepG2 respectively. However, other authors only refer to the $\mathrm{IC}_{50}$ of $100 \mu \mathrm{g} / \mathrm{ml}$ as potentially toxic to cell lines [38]. Moreover, the American National Cancer Institute (NCI) refer to an $\mathrm{IC}_{50}$ of less than $30 \mu \mathrm{g} / \mathrm{ml}$ to be toxic after an incubation period of $72 \mathrm{~h}$ [39], while others refer to $\mathrm{IC}_{50}$ of greater than $20 \mu \mathrm{g} / \mathrm{ml}$ as toxic [40].

From the MIC and $\mathrm{IC}_{50}$ values, we calculated the selectivity index (SI). SI indicates the cytotoxic selectivity or safety of the crude extract or isolated compound against the selected cell lines [41, 42]. The selectivity index of the derivatives was much higher compared to those of the parent compounds, suggesting the safety of the derivatives is much better compared to that of parent compounds. The derivatives exhibited high selectivity index values, indicating the wider difference between their cytotoxicity and antimicrobial activity.

\section{Conclusions}

The derivative compounds in the current study had better anti-mycobacterial activity compared to the parent compounds isolated from Curtisia dentata. The results

Table 1 Anti-mycobacterial activity of extracts, compounds and derivatives from C. dentata

\begin{tabular}{|c|c|c|c|c|c|c|}
\hline \multirow[t]{2}{*}{ Samples } & & \multirow[t]{2}{*}{$\mathrm{MIC}$ in $\mu \mathrm{g} / \mathrm{ml}$} & \multicolumn{2}{|c|}{ Cytotoxicity ( $\mathrm{gg} / \mathrm{ml})$} & \multicolumn{2}{|c|}{ Selectivity index } \\
\hline & & & HEK293 & HepG2 & HEK 293 & HepG2 \\
\hline \multirow[t]{4}{*}{ Fractions } & Acetone & 44.2 & & & & \\
\hline & Ethanol & $>50$ & & & & \\
\hline & Chloroform & $>50$ & & & & \\
\hline & Methanol & 22.2 & & & & \\
\hline \multirow[t]{4}{*}{ Isolated compounds } & $\beta$-sitosterol & $>50$ & $>300$ & $>300$ & 6 & 6 \\
\hline & Betulinic acid & $>50$ & $>300$ & $>300$ & 6 & 6 \\
\hline & Ursolic acid & $>50$ & 122.4 & $>300$ & 2.45 & 6 \\
\hline & Lupeol & $>50$ & 278.8 & 289.4 & 5.58 & 5.79 \\
\hline \multirow[t]{2}{*}{ Derivatives } & Betulinic acid acetate & 19.8 & $357.80 \pm 2.14$ & $358.20 \pm 2.23$ & 18.1 & 18.1 \\
\hline & Ursolic acid acetate & 3.4 & $340.02 \pm 4.12$ & $328.39 \pm 3.10$ & 100 & 96.59 \\
\hline \multirow[t]{5}{*}{ Positive controls } & & MIC in $\mu \mathrm{M}$ & & & & \\
\hline & Rifampicin & 0.02 & & & & \\
\hline & Isoniazid & 0.43 & & & & \\
\hline & Streptomycin & 0.25 & & & & \\
\hline & TMC207 & 0.02 & & & & \\
\hline
\end{tabular}

(Cytotoxicity data for isolated compounds has been extracted from [43]) 
obtained in this study suggests that even though the isolated triterpenes are inactive against selected $M$. tuberculosis species, they may be serve as a source for the development of potent anti-TB drugs. Furthermore, the derivatives were not toxic to the selected cell lines. There is a need to explore the cytotoxicity of the derivatives against other human cell lines to validate their cytotoxic effect. Overall, there is a need to explore the phytochemicals that may be embedded into the acetone fraction as it revealed moderate inhibition of the selected strains. This work serve as a template for the validation of $C$. dentata in the treatment of tuberculosis. We further need to explore the activity of the extracts, isolated compounds and other derivatives against various pathogenic Mycobacterium species.

\section{Acknowledgment}

The authors are thankful to the University of Cape Town, Malaria and TB unit for allowing us to work in their Laboratory.

\section{Funding}

We acknowledge the financial contribution of University of Zululand Research committee.

\section{Availability of data and materials}

Data and materials available

\section{Authors' contributions}

The biological assays analyses and writing the draft manuscript were done by VOF, ARO and NIM. TJM and PMD has critically reviewed the manuscript and participated in the study design and choice of assay methods. VOF assisted in isolation and NMR of the isolated compounds. TJM conceived the idea, reviewed the draft and final manuscripts and interpretation of results. All authors read and approved of the final manuscript for submission.

\section{Competing interests}

The authors declare that they have no competing interests.

\section{Consent for publication}

Not applicable

\section{Ethics approval and consent to participate}

Ethical approval/clearance was not required for this research project.

\section{Publisher's Note}

Springer Nature remains neutral with regard to jurisdictional claims in published maps and institutional affiliations.

\section{Author details}

'Department of Chemistry, University of Zululand, Private Bag X1001,KwaDlangezwa, Richards Bay 3886, South Africa. ${ }^{2}$ College of Agriculture and Environmental Sciences (CAES) Laboratories, Eureka Building-Laboratory 139, University of South Africa, Private Bag X6, Florida, Johannesburg 0710, South Africa. ${ }^{3}$ Department of Biochemistry \& Microbiology, University of Zululand, Private Bag X1001, KwaDlangezwa, Richards Bay 3886, South Africa. ${ }^{4}$ Research, Innovation \& Engagements Portfolio, Mangosuthu University of Technology, P O Box 12363, Durban 4026, South Africa.

Received: 15 November 2016 Accepted: 31 May 2017 Published online: 12 June 2017

\section{References}

1. Buzayan MM, El-Garbulli FR. Antibacterial activity of medicinal aqueous plant extracts against Mycobacterium tuberculosis. Malaysian J Microbiol. 2012;8:203-6.
2. Frieden TR, Sterling T, Pablos-Mendez A, Kilburn JO, Cauthern CA, Dooley SW. The emergence of a drug resistant tuberculosis in new York City. The New Engl J Med. 1993;328:521-6.

3. Migliori GB, Lange C, Centis R, Sotgiu G, Mutterlein R, Hoffmann $H$, Kliiman K, De Laco G, Lauria FN, Richardson MD, Spanevello A, Cirillo DM, TBNET Study Group: Resistance to second-line injectables and treatment outcomes in multidrug-resistant and extensively drug-resistant tuberculosis cases. Eur Respir J 2008; 31:1155-1159.

4. Simpson G, Coulter C, Weston J, Knight T, Carter R, Vincent S, et al. Resistance patterns of multidrug-resistant tuberculosis in Western Province, Papua New Guinea. Int J Tuberc Lung Dis. 2011;15:551-2.

5. Ahmad N, Javaid A, Sulaiman SAS, Ming LC, Ahmad L, Khan AH. Resistance patterns, prevalence, and predictors of fluoroquinolones resistance in multidrug resistant tuberculosis patients. Braz J Infect Dis. 2016;20:41-7.

6. Amoah SKS, Sandjo LP, Bazzo ML, Leite SN, Biavatti MW. Herbalists, traditional healers and pharmacists: a view of the tuberculosis in Ghana. Braz J Pharmacog. 2014;24:89-95.

7. McGaw LJ, Lall N, Meyer JJM, Eloff JN. The potential of South African medicinal plants against Mycobacterium infections. J Ethnopharmacol. 2008;119:482-500

8. Ofokwu RA, Ayoola A, Okwuobu CA. Medicinal plants used in the treatment of tuberculosis in humans and animals by Idoma tribe of north central Nigeria. Nigerian Vet J. 2008;29:25-30.

9. Tabuti JRS, Kukunda CB, Waako PJ. Medicinal plants used by traditional medicine practitioners in the treatment of tuberculosis and related ailments in Uganda. J Ethnopharmacol. 2010;127:130-6.

10. Arya V. A review on anti-tubercular plants. Int J PharmTech Res. 2011;3:872-80.

11. Semenya SS, Maroyi A. Medicinal plants used for the treatment of tuberculosis by Bapedi traditional healers in three districts of the Limpopo Province, South Africa. Afr J Trad Compl \& Alt Med. 2013;2013(10):316-23.

12. Lawal IO, Grierson DS, Afolayan AJ. Phytotherapeutic information on plants used for the treatment of tuberculosis in Eastern Cape Province, South Africa. Evidence-Based Compl Alt Med, Article ID. 2014:735423, 11 pages.

13. Kehinde $\mathrm{AO}$, Akintola $\mathrm{AO}$. Antibacterial activity of extract of Crinum jagus bulb against isolates of Mycobacterium tuberculosis. Afr J Biomed Res. 2015;15:129-33.

14. Ibekwe NN, Ameh SJ. Plant natural products research in tuberculosis drug discovery and development: a situation report on Nigerian biodiversity. Afr Biotech. 2014;13:2307-20.

15. Newton SM, Lau C, Gurcha SS, Besra GS, Wright CW. The evaluation of forty-three plant species for in vitro antimycobacterial activities, isolation of active constituents from Psoralea corylifolia and Sanguinaria canadensis. J Ethnopharmacol. 2002;79:57-67.

16. Bueno-Sanchez JG, Martinez-Morales J, Etashanko EE, Ribon W. Antitubercular activity of eleven aromatic and medicinal plants occuring in Colombia. Biomedica. 2009;29:51-60.

17. Nvau JB, Oladosu PO, Orishadipe AT. Mycobacterial evaluation of some medicinal plants used in plateau state of Nigeria for the treatment of tuberculosis. Agric \& Biol J North Amer. 2011;2:1270-2.

18. Enjale B, Berhan M, Mebrahtom G, Adane W, Gobena A. Evaluation of in vitro anti-mycobacterial activity of selected medicinal plants in Mekelle, Ethiopia. World Appl Scie J. 2014;31:1217-20.

19. Njeru SN, Obonyo MA, Nyambati SO, Ngari SM. Bioactivity of Cissampelos pareira medicinal plant against Mycobacterium tuberculosis. J Pharmacog \& Phytochem. 2015;3:167-73.

20. Nguta JM, Appiah-Opong R, Nyrko AK, Yeboah-Manu D, Addo PGA, Otchere I, et al. Antimycobacterial and cytotoxic activity of selected medicinal plant extracts. J Ethnopharmacol. 2016;182:10-5.

21. Coates Palgrave M. Trees of southern Africa. Third ed. Struik Publishers, Cape Town: Third Impression; 2005. p. 858.

22. Dold AP, Cocks ML. The trade in medicinal plants in the eastern Cape Province, South Africa. S Afr J Scie. 2002;98:589-97.

23. Fadipe VO. Design, synthesis, and biological evaluation of Antimycobacterial agents from plant derived betulinic acid, oleanolic acid and their derivatives. Doctor of Philosophy Thesis: Universty of Zululand; 2016.

24. Collins LA, Franzblau SG. Microplate Alamar blue assay versus BACTEC 460 system for high-throughput screening of compounds against Mycobacterium tuberculosis and Mycobacterium avium. Antimicrob Agents \& Chemother. 1997:41:1004-9.

25. Birdi T, D'souza D, Tolani M, Daswani P, Nair V, Tetali $P$, et al. Assessment of the activity of selected Indian medicinal plants against Mycobacterium 
tuberculosis: a preliminary screening using the microplate Alamar blue assay. European J Med Plants. 2002;2:308-23.

26. Mosmann T. Rapid colorimetric assay for cellular growth and survival: application to proliferation and cytotoxicity assays. J Immunol Methods. 1983;65:55-63.

27. Sreejaya SB, Santhy KS. Cytotoxic properties of Acorus calamus in MCF-7 breast cancer cells. Int J Curr Res Acad Rev. 2013;1:106-11.

28. Bagla VP, McGaw LJ, Elgorashi EE, Eloff JN. Antimicrobial activity, toxicity and selectivity index of two biflavonoids and a flavone isolated from Podocarpus henkelii (Podocarpaceae) leaves. BMC Compl Alt Med. 2014;14:383.

29. Raj R, Biot C, Carrere-Kremer S, Kremmer L, Guerardel Y, Gut J, et al. 7-Chloroquinoline-isatin conjugates: anti-malarial, anti-tubercular, and cytotoxicity evaluation. Chem Biol \& Drug Des. 2014;83:622-9.

30. Jyoti A, Zerin T, Kim TH, Hwang TS, Jang WS, Nam KW, et al. In vitro effect of ursolic acid on the inhibition of Mycobacterium tuberculosis and its cell wall mycolic acid. Pulmon Pharmacol Therapeutics. 2015;33:17-24.

31. Jyoti A, Nam KW, Jang WS, Kim TH, Kim SK, Lee BE, et al. Anti-mycobacterial activity of methanolic plant extract of Artemisia Capillaris containing ursolic acid and hydroquinone against Mycobacterium tuberculosis. J Infect Chemother. 2016;22:200-8.

32. Higuchi CT, Pavan FR, Leite CQF. Triterpenes and anti-tubercular activity of Byrsonima crassa. Quim Nova. 2008;31:1719-21.

33. Lambert P. Cellular impermeability and uptake of biocides and antibiotics in gram-positive bacteria and mycobacteria. J Appl Microbiol. 2002;92:46S-54S

34. Gupta S, Dwivedi GR, Darokar MP, Srivastava SK. Antimycobacterial activity of fractions and isolated compounds from Vetiveria zizanioides. Med Chem Res. 2012;21:1283-9.

35. Lall N, Das Sarma M, Hazra B, Meyer JJM. Antimycobacterial activity of diospyrin derivatives and a structural analogue of diospyrn against Mycobacterium tuberculosis in vitro. J Antimycrob Chemother. 2003;51:435-8.

36. Fadipe VO, Mongalo NI, Opoku AR. Antibacterial properties of Curtisia dentata leaves and some triterpenes/active principles isolated from them. Med Chem. 2014;4:125

37. Opoku AR, Fadipe VO, Mongalo NI. Selectivity index and antioxidant properties of extracts and a newly isolated active principle from Curtisia dentata (Burm.f) C.A.Sm (Curtisiaceae) leaves. S Afr J Bot. 2016; doi:10.1016/j. sajb.2016.02.145.

38. Hasibuan RPAZ. Cytotoxic effect of n-hexane, ethyl acetate and ethanol extracts of Plectranthus amboinicus, (Lour.) Spreng.) on HeLa and Vero cells lines. Int J PharmTech Res. 2014;6:1806-9.

39. Talib WH, Mahasheh AM. Antiproliferative activity of plant extracts used against cancer in traditional medicine. Sci Pharm. 2010;78:33-45.

40. Elisha IL, Dzoyem JP, Botha FB, Eloff JN. The efficacy and safety of nine South African medicinal plants in controlling bacillus anthracis Sterne vaccine strain. BMC Compl \& Alt Med. 2016;16:5.

41. Makhafola TJ, McGaw LJ, Eloff JN. In vitro cytotoxicity and genotoxicity of five Ochna species (Ochnaceae) with excellent antibacterial activity. S Afr J Bot. 2014;91:9-13.

42. Machana S, Weerapreeyakul N, Barusrux S, Nonpunya A, Sripanidkulchai B, Thitimetharoch T. Cytotoxic and apoptotic effects of six herbal plants against the human hepatocarcinoma (HepG2) cell line. Chin Med. 2011;6:39.

43. Fadipe VO, Mongalo NI, Opoku AR. In vitro evaluation of the comprehensive antimicrobial and antioxidant properties of Curtisia dentata (Burm.F) C.A. Sm: toxicological effect on the human embryonic kidney (HEK293) and human hepatocellular carcinoma (HepG2) cell lines. EXCLI J. 2015;14:971-83.

\section{Submit your next manuscript to BioMed Central and we will help you at every step:}

- We accept pre-submission inquiries

- Our selector tool helps you to find the most relevant journal

- We provide round the clock customer support

- Convenient online submission

- Thorough peer review

- Inclusion in PubMed and all major indexing services

- Maximum visibility for your research

Submit your manuscript at www.biomedcentral.com/submit
Biomed Central 